International Journal of Biology, Pharmacy and Allied Seiences (IJBPAS) 'A Bridge Betusen caboratory and Qender'

WwW.ijbpas.com

\title{
AYURVEDA FUNDAMENTALS TO MITIGATE AND PREVENT OF CONGENITAL ANOMALIES IN CHILDREN - A REVIEW
}

\section{KRISHNA RATHOD ${ }^{*}$, MANISHA DUNGHAV ${ }^{2}$}

1: PhD Scholar and Associate Professor MD. Ayurved Samhita and Siddhant,Parul Institute of Ayurved, Parul University, Vadodara, India

2: Professor, Ayurved Samhita and Siddhant, Faculty of Ayurved, Parul University, Vadodara, India

*Corresponding Author: Krishna Rathod: E Mail: krishna.rathod26816@paruluniversity.ac.in

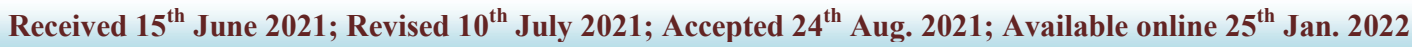

\section{https://doi.org/10.31032/ijbpas/2022/11.1.2036}

\section{ABSTRACT}

Background: Congenital anomalies are important causes of still births, infant mortality and are contributors to childhood morbidity. Congenital malformation represents defects in morphogenesis during early foetal life. The estimated 303000 newborn die in 4 weeks of birth every year, throughout the world due to congenital anomalies. Data reveals that $11.1 \%$ of pediatric hospital admissions are for children with genetic disorders, $18.5 \%$ are children with other congenital malformations. As per the Data to March of Dimes (MOD) global report on birth defects 7.9 million births (6\% of total births) occur annually worldwide with serious birth defects and $94 \%$ of these births occur in the middle and low income countries. According to joint WHO and MOD meeting report, birth defects account for $7 \%$ of all neonatal mortality and 3.3 million under five deaths. The prevalence of birth defects in India is 6-7\% which translates to around 1.7 million birth defects annually. The common birth defects include congenital heart disease (8-10 per 1000 live births), congenital deafness (5.6-10 per 1000 live births), and neural tube defects (4-11.4 per 1000 live births). Some birth defects are clinically apparent at birth; others may only be diagnosed during later stages of life. 
Material and Materials: The following are the databases followed- PubMed, Science direct, Google Scholar, DHARA, and AYUSH Portal. A search was undertaken in the Pub-Med database, using keywords Ayurgenomics, congenital anomalies, Prakriti, phenotype as the mesh term. There were 2692 articles available. Nine articles available in Google scholar and four articles from DHARA were also shortlisted. After using various filters only five articles were found most relevant and were considered as the reference for the present review. Textual references considered are the classics Charaka Samhita, Susruta Samhita, Ashtanga Samgraha and Ashtanga Hridaya with special reference to Shareera Sthana

\section{Conclusion:}

There are Multiple Causes of congenital anomalies which are associated with lack of supervision, care and prevention through diet, mode of action and mental health Multiple antenatal factors those influencing physical and psychological development of child are well described in Ayurveda.

\section{Keywords: Congenital Anomalies, Viruddha Ahara, Ayurveda Prevention and Mitigation}

\section{INTRODUCTION}

The congenital disorders in Ayurveda occurs due to defect in germ cells or somatic cells in the intra-uterine environment. The interaction in the germ cell genotype, geo-climatic \& uterine factors, mother's diet with all the activities of parents as well as the nature of Panchamahabhoota in the environment at the time of fertilization, determine the Prakriti (phenotype).Now About Ahara, Ahara not only nourishes the body it also nourishes the Manas. Ahara which are consumed by the subjects are in prepared form. Though subjects are using the Satwika Ahara, they are preparing and consuming along with Rajasika Ahara. In daily practice almost all the subjects were consuming food vegetables, grains, pulses etc., which are Rajasika Ahara. Some subjects used to consume junk food, bakery items, egg, leftover food which are Tamasika Ahara by reheating it. The unhealthy state of either factor and Constituion of Ahara can affect the prakriti of the fetus \& even result in congenital diseases. Ayurveda also supports different clan-Atulya gotra marriage, as consanguinity increases the risk of congenital anomalies. It is mentioned that a seed cultivated in a healthy field only can yield supreme variety of crop; the procedures to make the reproductive system healthy may prevent the occurrence of congenital disorders. The present original review article is to highlight on mitigating, preventive \& 
personalized approach towards congenital anomalies and disorder in Ayurveda. Congenital anomalies are categorized mainly in three types: where external form or structure is abnormal is structural anomalies, where function of an organ is affected at cellular level are functional anomalies and where there is any defect at the level of metabolism are metabolic anomalies. Ayurgenomics in Ayurveda is already existed under the umbrella of Beeja Shuddhi (gamete purification), Samshodhana (body

\section{DISCUSSION:}

Santanadosha - Santanadosha is an Umbrella term covering infertility, miscarriages, abortions, birth defects and congenital anomalies, genetic mutations and hereditary diseases etc of today's concern. While its further elaboration and exploration in CharakaSamhita as different factors responsible for congenital anomalies or Birth Defects. ${ }^{\mathrm{i}}$. These factors are Beeja DoshaShuddha Beeja (pure and healthy gametes) are basic pre-requisite for conception of healthy progeny. If there is shortcoming in Beeja or gametes, it leading to defects or anomalies in the child. Hence there is purification of gametes with the help of Samshodhana and Beeja Shuddhikara medicines have been explained in Ayurveda. purification) before conception, and administration of regimes and medicines to pregnant woman. While different congenital anomalies and birth defects are explained in Ayurveda as Santana Dosha. The root of this Santana Dosha or congenital anomalies has rooted in the Tridosha theory of Prakriti formation.

Mitigation and preventive personalized apparoach towards Anomalies through the application of Fundamental Principles of Ayurveda:

Aashaya: defects in the Garbhashaya is also responsible for the formation of congenital anomalies in children due to physical factors affecting the fetus in uterus.

Kala: Kala also have strong impact on the progeny, which may cause defects and anomalies in the child.

Dosha:Dosha are prime elements explained in Ayurveda responsible for vitiation and occurrence of diseases in human body. Different Dosha causes Different congenital defects. Dosha can affect either Beeja before conception or embryo (Garbha) after the conception. In both the way there is deformity or defect in the child.

Aatma Karma: Aatma is considered as divine force which drives the life of human being. Any derangement in this drive can gives rise to congenital defects in child. 
In modern genetics too there is theory of teratogenic agents and its teratogenic effects causing different congenital anomalies. Such a congenital defects are cleft palate, cleft lips, agenesis, and dysgenesis of different organs. Present research study has been proposed to explore and describe the role of Viruddha Aahara an etiological factor in the formation of congenital anomalies or birth defects.

The abnormalities happening in beeja (sperm \& ovum), beejabhaga (chromosome) \& beejabhaga avayava (gene) can be prevented up to an extent by bio-purification therapies before conception (garbhadhana poorva shodhana). It is mentioned that a seed cultivated in a healthy field only can yield supreme variety of crop. The practice of diet \& regimen suitable to the Prakriti right from the adolescent period may have very significant and far-reaching implications. Ayurveda emphasizes on pregnancy planning than an accidental conception. Strict practices to attain the reproductive health are mentioned, in many chapters of the classics. A healthy couple has to follow certain regimens, bio-cleansing measures, to enhance fertilization \& to get the desired progeny. Administration of milk \& ghee by male and oil (sesame/Masha oil), horse gram to female, may be practiced from the adolescent period onwards. Satisfactory results may be expected if the treatment is started well in advance before conception by considering the Dhatu parinama kala (time taken by the nutrients to reach in all the seven Dhatu). Thus, by proper monitoring and screening of male $\&$ female right from adolescent period onwards with an education to adopt diet \& lifestyle, that is suitable to their Prakriti may help to achieve a healthy reproductive system as well as overall health. The preventive measures for Janmabala pravritha roga include the use of Prajasthapana gana (a group of ten drugs for protecting the foetus) and Jeevaneeya oushadha (a group of ten drugs for promoting longevity) ${ }^{9}$ with an aim to assure healthy nutrition to the mother. Ayurvedic literatures are the hidden treasures of many ideas that extend up to the level of genetic theory. The description of beeja, beejabhaga, beejabhagavayava, practices to acquire a healthy child, monthly regimens for pregnant lady are elaborated vividly to consider progeny as the greatest wealth.Garbhani Paricharya described in our Ayurvedic literature has direct scientifically approach towards development of healthy fetus inside the womb of pregnant mother without having any birth defect. It plays a significant role in stabilization of Garbha along with meet the essential nutrient and energy requirement 
necessary during pregnancy.Chakrapani has clarified the views of Charaka and said that suppression of acute desires may cause death of the fetus, but milder ones may ensure abnormalities. Maharsi Kashyap has described the adverse effect of the smoking of the mother during pregnancy. If the pregnant mother indulges in such activities they are supposed to produce various congenital abnormalities blindness, sickness, discoloration of the new born baby and even Garbhapata or abortion. These all type of descriptions Guna (good deeds) of parents are concerned with healthy and normal development of organs of the fetal body. Avagun (Bad deeds) are concerned with congenital malformations and development errors like cleft palate, hare lip and imperforate anus.Those women, who are devotee to God, pursue Brahman like deeds and those who observe modest and beneficial life style give birth to virtuous and genius child. Whereas contrary conduct of mother during pregnancy period produces various anomalies in offspring.

The Mitigate measures for Monitoring the diet and regimen Maturahara vihara Prakriti before conception may help to prevent congenital anomalies to some extent. Aahara and Vihara : it is very important and basic factor to be considered in any kind of diseases in Ayurveda. Hence Santanadosha will also not an exception for this. As per Ayurveda Aahara gets transformed in to Beeja (Shukra and Shonita) as last or terminal Dhatu which have capacity to produce fetus. Aahara which vitiates the Dosha is responsible for vitiation of Beehja (gametes). Vitiated or defected gametes are basic factor for formation of fetal defect or congenital anomalies. Beeja are consist of fundamental units called Beejabhaga and Beejabhagvaya. If there is complete vitiation of Beeja there will be no survival of fetus or there will be no fertilization at all, while if there is vitiation of Beejabhaga and Beejabhagavayava there is formation of viable fetus but with different congenital anomalies or defects according to the part of Beejabhaga gets vitiated. Viruddhaahra is one of the factor which is responsible for the vitiation of Beejabhaga, Beejabhagavya and causing Santanadosha or congenital anomalies in fetus. Each Prakriti has specific physical and psychological attributes -Guna based on the Dosha involved in their constitution. Every individual must maintain their balance of Dosha as determined by their Prakriti in order to remain healthy. Even though, food is derived by individual from the environment, its processing \& use intimately depend on the integrity of internal 
bio-mechanism. Unless the bio-fire systemAgni \& inner bio-transport-Srotas are in order, the process of nutrition may not accomplish.

The Personalized Measures for Pregnant women consuming Vata Dosha vitiating diet causes deaf, dumb, hoarse or nasal voice, lame, dwarf, number of body parts. Pitta Dosha vitiating diet causes Baldness, premature graying of hairs, absence of hairs on face, tawny color of skin, hair and nail. Kapha Dosha vitiating diet causes Kushta (leprosy), Kilas (type of skin disorder) and congenital presence of teeth ${ }^{[5]}$. Regular use of Wine causes over thirsty, short memory $\&$ unstable mind. Frequent use of fish causes fixed eyes or delayed dropping of eye lids. Daily excessive use of sweet substances except milk Suffers from Prameha, obesity and dumbness. Daily excessive use of pungent or bitter (Tikta) articles suffers from emaciation or edema, weakness and weak digestive capacity. Daily excessive use of astringent (kashaya) articles causes black/ dark complexion, suffer from Anaha. Daily excessive use of salty (lawan) articles causes early wrinkling, graying of hairs and baldness. Daily excessive use of sour ( $\mathrm{Amla}$ ) articles causes bleeding disorders, Skin and Eye disorders. Daily excessive use of bitter, hot (Katu) articles causes weakness, possess less quantity of Shukra, develops infertility. The influence of Ahara on Manas Bhavas but whether it is influenced positively or negatively and in what extent is unidentified. Manas is also influenced by confounding factors like work, environment, place etc. Hence it can be concluded that Manas is not only influenced by Ahara, it is also influenced by other confounding factors.

\section{COCLUSION:}

There are Multiple Causes of congenital anomalies which are associated with lack of supervision, care and prevention through diet, mode of action and mental health Multiple antenatal factors those influencing physical and psychological development of child are well described in Ayurveda. An integrated and Personalized strategy combining best possible patient care, with prevention by community education, population screening, genetic counseling, and the availability of prenatal diagnosis should be adopted. By following the various principles mentioned in Ayurveda i.e. Dietary regimen related to Garbhini Paricharya, avoiding Garbhop-ghatkar Bhava and Tridosha vitiating diet during pregnancy can avoid various anomalies during pregnancy. This concept establishes that patient care by Mitigation and prevention are not 
compromised alternatives but are complementary, obligatory inseparable aspects for healthy offsprings.

\section{REFERENCES:}

[1] WHO (2016) Child Causes of Death, Estimates for2000-2015.

[2] Scriver CR, Neal JL, Saginur R, ClowA.,The frequency of genetic disease and congenital malformation among patients in a pediatric hospital; Can Med Assoc J. 1973;108:1111-5 [PubMed]

[3] Agnivesha, Charaka Samhita Volume I, SharirSthana (Charaka and Dridhabala with Chakrapani commentary and Vidyotini Hindi commentary) $6^{\text {th }}$ edition, Chowkhamba Sanskrit Santhana, Varanasi Prakashan; 2000; 574

[4] Periyasamy Govindaraj et al. Genomewide analysis correlates Ayurveda Prakriti. http:// www.nature.com/scientificreports /5:15786 | DOI: 10.1038/srep15786.

[5] Charaka Samhita, Edited by Sharma PV; Chaukhambha Orientalia, Varanasi; Reprint edition 2014.

[6] Banerjee S, Debnath P, Debnath PK. Ayurnutrigenomics: Ayurveda inspired personalized nutrition from inception to evidence. J Tradit Complement Med.
2015 Mar 24;5(4):228- 33. doi: 10.1016/j.jtcme.2014.12.009.

[7] Subhojit Dey, Parika Pahwa. Prakriti and its associations with metabolism, chronic diseases, and genotypes:

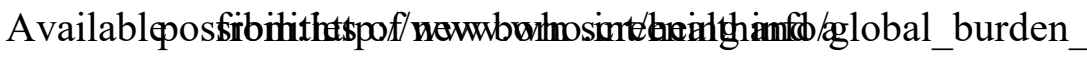

lifetime of personalized prevention.

http://www.ncbi.nlm.nih.gov/pubmed/2 4812471.

[8] http://www.who.int/gho/child_health/m ortality/neonatal/en/ Global Health Observatory (GHO) data / Child mortalityand causes of death

[9] Jiao X, Kabir F, Irum B et. al. A common ancestral mutation in CRYBB3 identified in multiple consanguineous families with congenital cataracts. PLoS One. 2016 Jun 21;11(6):e0157005. doi: 10.1371/journal.pone.0157005.

[10] Susruta Samhita, Dalhana Commentary: Edited by Acharya Jadavji Trikamji. Chaukhambha Orientalia, Varanasi; Reprint edition 2014.

[11] Ashtanga Samgraha Edited by Murthy Srikantha K.R.; Chaukhambha Orientalia; Varanasi: Reprint edition 2012.

[12] Gupta PD. Pharmacogenetics, pharmacogenomics and ayurgenomics 
for personalized medicine: a paradigm shift. Indian J Pharm Sci. 2015 MarApr;77(2):135-41.

[13] Umarkar Suwarna V., Vyas Deepak M., Sathe Kalpana D., Kulkarni Sheela B. Case series study of different predominant Deha prakriti with special reference to Fitzpatric skin type classification. Int. J. Res. Ayurveda Pharm. 2013;4(6):797-799 http://dx.doi.org/10.7897/2277-

4343.04603 